\title{
CARNIVAL FASHION CREATIVITY AT MALANG FLOWER CARNIVAL (MFC)
}

\author{
Agus Sunandar ${ }^{1}$ and Dharsono ${ }^{2}$ \\ ${ }^{1}$ State University of Malang, Indonesia \\ ${ }^{2}$ Indonesian Insitute of the Arts Surakarta, Indonesia \\ E-mail correspondence: samsuga72@gmail.com
}

\begin{abstract}
Malang Flower Carnival (MFC) which has worldwide, the results of the creation of these activities have been staged in various countries in the world. MFC has successfully entered the COE (Calender of Event) of the Indonesian Ministry of Tourism 3 times. The existence of this event supports and strengthens the predicate of Malang City as a Creative City in Indonesia. This success is interesting to do a study of how the fashion creativity that has been created from the MFC. This study uses a qualitative approach specifically Roland Barthes's fashion function theory and Edmund Burke Feldman's function theory of art. The results of the study showed that the creativity of the carnival dress appeared in the visualization of the shape of hair such as temples, gold ornaments, ornamental elements, and body gestures that symbolized the beauty of local dance. In addition, the carnival costumes can be a representation of local culture as an idea of creation. Implementation of a fashion carnival can encourage community creativity which ultimately increases public welfare.
\end{abstract}

Keywords: Carnival fashion, local culture, creativity, and MFC

\begin{abstract}
ABSTRAK
Malang Flower Carnival (MFC) yang telah mendunia, hasil kreasi dari kegiatan itu telah dipentaskan di berbagai negara di dunia. MFC telah berhasil masuk ke dalam COE (Calender of Event) Kementerian Pariwisata RI sebanyak 3 kali. Keberadaan event ini ikut mendukung dan memperkuat predikat Kota Malang sebagai Kota Kreatif di Indonesia. Keberhasilan tersebut menarik untuk dilakukan kajian tentang bagaimana kreativitas busana yang telah dihasilkan dari MFC. Kajian ini menggunakan pendekatan kualitatif khususnya teori fungsi pakaian Roland Barthes dan teori fungsi seni Edmund Burke Feldman. Hasil kajian menunjukkan bahwa kreativitas busana karnaval tampak pada visualisasi bentuk rambut seperti pura, hiasan warna emas, unsur ornamen, dan bentuk gesture tubuh yang melambangkan keelokan tarian lokal. Selain itu, busana karnaval tersebut bisa menjadi representasi budaya local yang dijadikan sebagai ide penciptaan. Penyelenggaraan karnaval busana dapat mendorong kreativitas masyarakat yang pada akhirnya meningkatkan kesejahteraan masyarakat.
\end{abstract}

Kata kunci: Busana karnaval, budaya lokal, kreativitas, dan MFC 


\section{Artistic}

\section{Introduction}

Since 1962 Malang is famous for the slogan Tri Bina Cita Kota Malang, namely Malang as the City of Education, Malang as the City of Tourism and Malang as the City of Industry. To fulfill that goal, Malang City always gives a big portion to the development of creative industries. Community creativity is divided into $16 \mathrm{sub}-$ sectors of the creative industries that have been launched by Bekraf. Malang has three superior sub-sectors namely culinary, game application, and fashion. Because of this achievement, Bekraf finally established Malang City as Indonesia's Creative City in 2019, even with a Special mention of the City with the Best Creative Ecosystems in Indonesia.

Malang Flower Carnival (MFC) which is carried out by the routine community every year in Malang becomes a form of creative activity. This carnival is included as the prime program to support the city of Malang as a Creative City. MFC has received three awards from the Ministry of Tourism of the Republic of Indonesia, and has

successfully entered the Calender Of Event (COE) at Wonderful Indonesia. One hundred of the best events in Indonesia were selected and included in the COE. The success of MFC in COE for 3 times has strengthened the predicate of Malang as the creative city of Indonesia.

Carnival in Indonesia has become a routine event in various regions, in fact there are lot of activities in various forms. MFC Carnival in Malang has unique characteristics and different costumes from other carnival. The MFC carnival dress always uses the theme of flowers and has the same function, namely as a medium for the introduction of Malang's identity as the City of Flowers. MFC was chosen as a discussion in this paper, because MFC has been developing from year to year and has motivated many people to participate in making flower carnival costumes and participate in the carnival event.

MFC is one of the biggest carnivals in Indonesia, which has a special characteristic, namely a costume parade with basic and main decorations in the form of flowers. This carnival is held every year by MFC Community, Malang City Government, arts and culture activists, students of the Department of Fashion at the 
State University of Malang (UM) and the participation of the wider community (Sunandar, 2016). Costumes displayed in carnivals are usually large, giving a monumental and glamorous impression. The materials used are derived from waste materials and used goods. This activity has been able to attract the interest of spectators ranging from local to foreign tourists. In addition, this activity has become a routine agenda of tourism in Malang City and even East Java Province. The existence of this carnival has brought the name of the Indonesian to the international level. The carnival committee always combines fashion, dance and percussion music both traditional and contemporary. It is done to support the implementation of MFC.

The purpose of this paper is to focus on the MFC carnival costumes to explore the values of creativity in the carnival fashion which won the first place in Malang Flower Carnival. This needs to be discussed in detail so that the carnival will not only be an annual event of a commercial but can also provide social functions that benefit the community.

\section{Literature Review}

In the Big Indonesian Dictionary, it is explained that carnival is parade activities carried out based on certain celebrations. The carnival can be used for several events, especially as a medium for cultural preservation. One of the main components in carnival activities is the form of costumes or carnival fashion. Carnival fashion is a manifestation of the artist's creativity in the fine arts that can produce various perceptions from the audience (Setiawan, 2010). The function of the carnival fashion, are: (a) can produce perceptions that are free to be interpreted by the audience, (b) functions as a science that carries the messages contained in fashion, (c) the function

of art that is the main or basic function, and social functions physically (Setiawan, 2010).

Carnival events are mostly held in East Java. Almost all cities or districts in East Java Province have carnival events that are held routinely every year. Jember Fashion Carnival (JFC) is the first modern and world-class fashion carnival event in Indonesia held in Jember. From Jember heading east a little, there is also the 


\section{Artistic}

Banyuwangi Ethno Carnival (BEC) in Banyuwangi. Furthermore, in Surakarta Central Java there is the Solo Batik Carnival (SBC) which specifically uses the theme of batik in each of its activities. SBC has a local content that is batik which is processed or created into a carnival costume (Rizqino, 2015).

Recently, many regions in Indonesia are using carnival activities as the main agenda for tourism destinations in their own regions. Most of them make carnival events as a way for branding and promoting their regions. Fashion carnival activities are implemented as part of regional city branding. Branding efforts are usually carried out using promotional tools. One form of the promotional tools is the implementation of event (Belch, 2003 in Dian Cahyani, 2014).

Fashion carnival which has become a phenomenon in several regions in Indonesia, if traced to the past through art history, can be drawn a common thread that carnival has the same form and spirit as traditional art that is held in public open spaces, namely the streets, but has a different purpose. In general, traditional ceremonial arts were carried out with religious purposes, "selamatan" or "ruwatan" or prayer to obtain safety and prosperity in the future. While the new carnival activity aims to celebrate the excitement with unique and spectacular artistic creations for the

purpose of attracting tourists and introducing identity and advancing the city (Denissa, 2012).

Fashion in carnival is inseparable from the element of creativity. Creativity is the strength of humans comparing from animals, machines, and computers (Tabrani, 2017). The definition of creativity is as follows:

Creativity is one of the human abilities that can help other abilities, so that as a whole can integrate external stimulus (which engulfs its senses from outside now) with internal stimulus (memory that has been previously owned) to create a new roundness (Tabrani, 2017).

The ability to create possessed by humans in the art world is often called the idea of work. This idea contains a dense explanation of the concept or idea of creativity to express the content into the form of art - theater, dance, music, film, fine arts, and others (Dharsono, 2016). 


\section{Method}

This research is a research about art, that is a research that places art as an object (Guntur \& Sugihartono, 2015). The type of research chosen was a qualitative research with aesthetic approach. Aesthetics is a philosophical study based on the apirori value of art (Dharsono, 2007). The values contained in this MFC fashion carnival are the focus of this study. Data collection techniques uses purposive sampling, where researchers chose one of the best works in the MFC fashion carnival as the object of study, that is the $1^{\text {st }}$ winner costume at Malang flower carnival in period 2016. The fashion work uses the theme of Balinese culture.

The data collection method uses observation, documentation, and literature study. Observations and documentation were carried out on the best fashion works in the MFC event. Observation results are verified by literature study and then did the data analysis. The data analysis used is Roland Barthes's fashion function theory and Edmund Burke Feldman's art function theory (Setiawan, 2010). The analysis theory is used to describe the value of the fashion's function of the MFC event as a medium for cultural preservation and improvement of people's creativity.

\section{Discussion}

\subsection{Visualization of MPC Carnival Fashion}

In 2016 the MFC event used a different theme from the previous year in the form of the Archipelago Cultural Festival. Malang Flower Carnival 2016 requires each participant to use the theme and background of the work based on the culture and traditions of their own regions. Carnival costumes of participants must follow the rules and regulations set by the organizing committee, the costumes must be at least $50 \%$ using flower-shaped decorations. Participants must insert the values of cultural traditions into the visualization of contemporary costume designs. It is a combination of tradition and modernity, or combining Western and Eastern cultures to get design results that are in line with the times but have an original cultural basis. 


\section{Artistic}

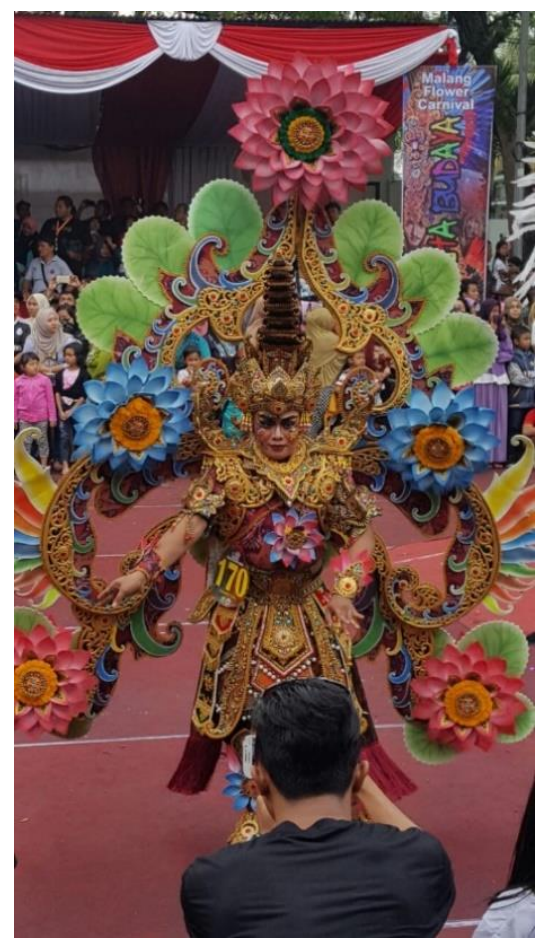

Figure 1. Padma Nusa costume

$1^{\text {st }}$ Winner in Malang Flower Carnival 2016

(Photo: Agus Sunandar, 2016)

The study of the carnival costume is based on the principles of the layout. The essence of a good composition is if a process of setting the elements forming the artwork always pay attention to the principles of composition, such as; harmony, balance, contrast, unity, simplicity, accentuation, and proportion (Dharsono, 2016). The visual elements in the carnival costume appear in a harmonious arrangement of colors, lines, textures and shapes. Decoration motifs in the form of "padma" or lotus flowers are made in various sizes as an implementation of repetition (rhythm).

\subsection{Value of Creativity \& Function of Carnival Fashion}

The carnival costume with the Padma Nusa theme above, has a high value of creativity. The combination of a variety of different visual elements and contrast in a unity, becomes the point of interest and strength in this work. Harmony is not always achieved by the uniformity of visual elements, but also by contradicting things or contrasting one another. 
Padma Nusa as a work seems to successfully present and integrate local cultural values, namely the local content of Bali. The combination seemed very harmonious with the theme determined by the committee, that is the flower carnival. The creativity values from the designer are able to answer the criteria of the carnival costume committee which must be glamorous, very detailed, and full of ornament and monumental, but still must be ergonomically worn by the model when performing along the carnival runway.

Analysis of the carnival fashion from the aspect of function is carried out according to the theory of Roland Barthes. From the analysis obtained the function values in the carnival fashion, namely:

a. The function of perception, that the carnival fashion produces an interpretation for the audience in the form of Balinese culture.

b. The function of science, that in the carnival fashion, there is knowledge that lies behind its making, included fashion-making techniques, identities carried from existing materials and colors, and the variety of decoration used. In the analysis also revealed the elements that make up a carnival fashion, those are elements of physical knowledge and elements of culture - meaning.

c. The function of exploration and identification, namely the exploration of the idea in making clothes and identification of Balinese cultural values contained in the fashion.

d. Communication function, i.e. indirectly the carnival fashion communicates to the audience or the people who see and the environment. Fashion is present at a carnival, an event which is a communication tool and a means of interaction between the designer and the consumer / audience. The communication that occurs in this carnival is a non-verbal communication, a communication that can affect the audience, either in the form of motivation or admiration.

From the above analysis it can be found that the functional aspect of the carnival fashion, as Edmund Burke Feldman said, art is a natural human mind and concepts that are arranged and packaged as a means of delivering messages to others 


\section{Artistic}

(Setiawan, 2010). The means of delivering the message is part of the communication function of art. Communication is a set of tools that are not intended to regulate how artists work, but rather look at the results and function value of the created artwork. In the end, art as a product and communication tool continues to be created by artists and the idea of creating art continues to develop, along with the evolution that occurs in the art world itself.

Three functions of art according to Feldman, namely main or basic functions, social functions, and physical functions (Setiawan, 2010). The analysis of those three functions are explained as follows:

a. Main or Basic Functions

The main or basic function is a function that emphasizes to the element of a person's ability in creativity. This creativity is closely related to the role of carnival fashion designers in producing varied works. MFC carnival fashion shows a high creativity process, where designers are required to be able to translate the traditional culture as a basic idea which is then developed into an aesthetic form of carnival fashion. The development is carried out without leaving the values contained in the culture.

b. Social Function

A carnival fashion is said to have a social function if the fashion is able to have a dialogue with the audience, and can influence the audience in a general situation and describe the togetherness in life (the spirit of togetherness). If the outfit is often used as a topic of conversation, it also indicates that it can attract the audience's interest to come watch and appreciate the outfit directly.

c. Physical Function

Physical function is the value of the use function of a fashion that is able to meet human physical needs. In the context of this carnival fashion, what is meant by physical value is the value of wearing clothes, namely as a carnival fashion and the use of ornamental variations in the design composition. The physical function will produce psychological functions, namely the fulfillment of audience 
satisfaction with aesthetic experience.

From the analysis above shows that the carnival fashion has the concept of Balinese culture, reflected in the shape of hair like temples in Bali, gold decoratives, ornamental elements, and body gestures that symbolize the beauty of dance in Bali. In addition, it can be said that the carnival fashion functions as a representation of Balinese culture and has elements of Balinese art.

This MFC carnival activity is important for cultural preservation efforts and developing the community creativity. The carnival can influence and encourage the creativity of the community, especially for those who participate as carnival participants. Carnival which is an annual activity that is carried out in almost all regions in Indonesia, and each carnival has significant differences in both the visual elements and the meaning contained in fashion. This creativity will lead to the improvement of people's welfare.

The benefits of this MFC activity include (1) as a means of attracting domestic and foreign tourists, (2) as a medium to revive the glory of Malang as Malang City of Flowers / Malang Kota Bunga (MAKOBU), (3) motivating people to have awareness about cultural preservation, (4) as an entertainment media and an introduction to the potential of local arts and culture, (5) improving the economy, especially culinary, souvenir sales and hotel lodging services.

MFC can function as a medium for introducing culture and enhancing creativity, both in training in making carnival fashion or participating in carnival participation. Every year the implementation of this carnival activity increases participation from both the number of participants and the number of spectators. This shows that this activity was accepted by the community and had a sustainable social and economic impact for the community continuously.

\section{Conclusion}

MFC is an annual carnival activity in Malang, East Java. This activity has been awarded by entering into the COE (Calender Of Event) Ministry of Tourism of Republic Indonesia for 3 times. The existence of this event supports and strengthens 


\section{Artistic}

the predicate of Malang City as a Creative City in Indonesia.

MFC activities have shown its benefits as an effort to preserve culture and develop the community creativity. The implementation of a fashion carnival can encourage people's creativity. In addition, the visualization of hair shapes such as temples, golden decorations, ornamental elements, and body gestures symbolize the beauty of local dances. The carnival fashion can be a representation of local culture where the culture is used as an idea of the creation. Creativity can be seen in the ability

of participants to apply local culture as ideas in creating fashion. This creativity will lead to the improvement of community welfare and good imaging of Malang City.

\section{References}

Dharsono. (2007). Estetika. Rekayasa Sains.

Dharsono. (2016). Kreasi Artistik, Perjumpaan Tradisi Modern dalam Paradigma Kekaryaan Seni. LPKBM Citra Sain.

Dian Cahyani, I. (2014). Implementasi Jember Fashion Carnival, sebagai Bagian dari City Branding Kabupaten Jember. journal.unair.ac.id

Guntur, \& Sugihartono, R. A. (2015). Metodologi Penelitian Artistik. ISI Press \& P3AI ISI Surakarta.

Rizqino, Q. (2015). Estetika Tata Susun Kostum Solo Batik Carnival. Pascasarjana ISI Surakarta.

Setiawan, D. (2010). Analisis Fungsi Pakaian Karnaval di Yogyakarta menurut Roland Barthes dan Fungsi Seni Edmund Berke Felmand. researchdashboard.binus.ac.id

Sunandar, A. (2016). Proposal Kegiatan Malang Flower Carnival Archipelago Cultural Festival.

Tabrani, P. (2017). Potensi Manusia: Kreativitas. Penerbit ITB. 